Mário Felipe de Lima Carvalho

Universidade do Estado do Rio de Janeiro, RJ, Brasil

\title{
Is Our Hope Cyborg? Subalternity, Recognition and "Tretas" on the Internet
}

Abstract: This article is based on considerations about the limits and potentialities in the production of solidarity, through reciprocal recognition, in social interactions mediated by technology, involving mainly trans activists. Based on concepts of symbolic interactionism in face-to-face social interactions, I regard the conflicts present in political interactions on the internet and the transformation of "potential allies" into "enemies" or "adversaries" in the political struggle. In this analysis, I try to understand the political-academic exchanges involving categories such as "subalternity" and "intersectionality" in order to enter the delicate debate about the greater or lesser appreciation of political positions based on the "standpoint" of the subject and of his or her interlocutor.

Keywords: Brazil; Recognition; Subalternity; Social Movements; Internet.

\section{(c) (i)}

Esta obra está sob licença Creative Commons.

1 I use here travestis, mulheres transexuais and homens trans as emic categories through which certain collectives identify themselves in the political arena. It is important to point out that, despite the efforts, both in the political and in the scientific level, to define what travesti or transexual is, the everyday use of those terms by those who utilize them as identity categories is rather diverse, with the same person identifying herself as travesti or transsexual, depending on the context (CARVALHO, 2011). There is, however, a relative consensus regarding the use of the term
"We" did not originally choose to be cyborgs, but choice grounds a liberal politics and epistemology that imagines the reproduction of individuals before the wider replications of "texts". [...]

These real-life cyborgs are actively rewriting the texts of their bodies and societies. Survival is the stakes in this play of readings. Donna Haraway (A Cyborg Manifesto)

\section{Introduction}

The movement of travestis, mulheres transexuais and homens trans in Brazil, or simply trans movement ${ }^{1}$, was my main object of study throughout my masters and $\mathrm{PhD}$ research. While writing my doctoral dissertation, I realized that a great part of my field material was internet-based, mainly Facebook, some blogs and YouTube channels. It is an undeniable fact that the new digital platforms of social interaction have been incorporated, modified and resignified 
"trans people" to encompass the different characteristics of identity, as well as the use of movimento de travestis, mulheres transexuais e homens trans as way to include the different political subjects as part of the movement. On a daily basis, the use of trans movement is a form of including all those individuals.

${ }^{2}$ I thank the anonymous advisor for the attentive reading, comments, criticism and suggestions. I also thank Larissa Pelúcio, Richard Miskolci and Jorge Leite Jr fo encouraging the publication of this article; Lucas Tramontano for the endless conversations that were responsible for many considerations here included; and, last but not least, Gustavo Capanema fo helping to write this English version of the original article.

${ }^{3}$ Treta is an emic category used to refer to a set of conflicts and fights (textual, oral, in video or through images), frequently used by young people to refer to situations either online or offline. Despite the fact that, in the scope of this article, I focus on online tretas, it is not possible to determine if the use of the category is restricted to a given arena, there being tretas that initiate online and continue offline and vice versa. In this regard, the most correct would be to characterize the use of treta inside an online/offline continuum.

${ }^{4}$ In Brazil, the expression used is "lugar de fala" which denotes the place from where a person may speak. This idea is based on Gayatri Spivak's classical text "Can the subaltern speak?" and therefore it makes allusions to a series of social markers of difference such as gender, sexual orientation, class, race, place of birth, generation, etc. in their political and social uses. It is also undeniable that these same platforms have allowed the diffusion of alternative regimes of visibility for trans people (as well as other socially minoritised groups). In this way, I do not take into account the meanings and reappropriation of the new information and communication technologies through their use by activists on social networks sites, but actually the activist interactions on digital networks regarding practices and strategies for political persuasion².

This article starts from considerations about the limits and potentialities for the production of solidarity, through reciprocal recognition, in social interactions mediated by technology involving mainly trans activists. Based on concepts of symbolic interactionism in face-to-face social interactions, I will talk about current conflicts in political interactions on the internet (the "tretas" 3 ) and the transformation of "potential allies" into "enemies" or "adversaries" in the political struggle. In this analysis, I try to identify the political-academic exchange involving categories such as "subalternity" and "intersectionality" in order to set foot into the delicate debate over the greater or lesser appreciation of the political stances based on the "standpoint" 4 of the subject and of his or her interlocutor.

Before these considerations, it is necessary to clarify that the use of notions such as "solidarity" and "reciprocal recognition" is based on the Theory of Recognition of Axel Honneth (1992, 1995 and 2003), in which there would be three forms of recognition: (i) the primal relations of love and friendship; (ii) legal relations related to rights; and (iii) the solidarity in the community. Following this model, the demand for facilitating name and sex alteration in civil registry as the main example of struggle for legal recognition of trans people is limited only to one aspect of the deprivation of rights process and, therefore, would not include other forms of disrespect that affect "dignity" more directly, such as offense, physical aggression and murder. The previously mentioned situations are, consequently, within the framework of the third form of recognition described by Honneth (1995): "solidarity".

According to the author, "solidarity" derives from a "social esteem" that allows persons to build a positive relation with their capacities and concrete properties, being, as a consequence, related to the personal characteristics that differentiate people. In this sense, proper social recognition needs a mediation process that universalizes the possibilities of difference. What the author calls "cultural self-understanding of a society" would operate such mediation:

a symbolically articulated - yet always open and porous

- framework of orientation, in which those ethical values 
${ }^{5}$ The Brazilian sociologist Berenice Bento (2014) suggests categorizing this kind of murder as "transfemicide", in order to highlight the gender as a reason for violence, distinguishing these murders from others with homophobic (against gays and lesbians) intention.

\footnotetext{
${ }^{6}$ For further discussion about trans activism on the internet in Brazil, see Mario Felipe de Lima Carvalho (2015) and Mario Felipe de Lima Carvalho \& Sérgio Carrara (2015)
}

and goals are formulated. [...] The cultural selfunderstanding of a society provides the criteria that orient the social esteem of persons, because their abilities and achievements are judged intersubjectively according to the degree to which they can help to realize culturally defined values. (HONNETH, 1995, p. 122)

The experiences of disrespect can involve different levels of recognition when the individual expectations are not met in social interaction. These situations will be further analyzed throughout the text, especially when it comes to "tretas".

Finally, one could argue that the recognition perspective proposed by Judith Butler (2006, 2015a and $2015 \mathrm{~b}$ ) would be more useful when considering the life of trans people, since the author assumes a perception of the recognition processes through negation, which means that the recognition would happen in the universality of human vulnerability in the face of death. In her model of "nonviolence ethics", the author states that the impossibility of manifesting public mourning would be the most drastic lack of recognition. Thus, the unrecognized deaths, the unmournable ones, would evidence the non-recognition of the individual's own humanity. Indeed, Butler's proposal is very useful for us to think about the systematic murder of trans people in Brazil as well as the negligence on the part of legal and police authorities in the effective investigation and punishment of culprits ${ }^{5}$. However, my focus on this article is in the processes of social interaction on the internet, in which activists seek the production of alternative regimes of visibility for trans people, through the appreciation of their lifestyles, which is more aligned with Honneth's proposal described previously.

Following these introductory considerations, I am presenting a brief overview of trans activists repertoires, followed by an outline of some contributions of symbolic interactionism to the studies of social interactions on the internet. Finally, I am considering the delicate debate over the conflicts through the identification of allies or enemies present in discursive productions of activists on the digital network.

\section{The Repertoires of Trans Cyberactivism}

One of the most common contexts of debate between trans activists and a heterogeneous public is the area dedicated to comments on news in internet portals ${ }^{6}$. Different activists systematically stress the non-recognition of gender on news that use constructions such as "o travesti" or "o transexual", using the Portuguese masculine article "o" to 
7 Carioca is something or someone from Rio de Janeiro. refer to people that see themselves in the feminine. They also highlight news stories and opinion pieces that build a derogatory view on trans people, usually associated with criminal activities, prostitution and drug trafficking, among other transphobic situations, whether implied or explicit. At times, such comments generate debates between different portal readers, who sometimes support the statements of the activists, sometimes strongly oppose them with hate speeches or even accusing these activists of "pestering" people. Comments like "stop being annoying", "that's nitpicking" or "don't you have anything else to do?" clearly evidence a non-recognition of the moral and political validity of the activist claim. In this way, the non-recognition of the verbal, physical or symbolic violence creates a system of feedback and moral validation of violence.

Another use of the internet for activism is to denounce violence against trans people, almost always lethal. The absence of even the possibility of a specific notification in the case of the murder of travestis and trans women makes transfemicide a phenomenon that is difficult to measure. The estimates on the number of murders are based on news stories and reports on social networks sites. However, such systematically patterned reports, usually followed by pictures of stabbed, disfigured or even dismembered bodies, raise a debate over the spectacularization of violence.

Based on a survey on the number of murders of gay men and travestis between the 1970's and 1990's in Rio de Janeiro, Sérgio Carrara and Adriana Vianna (2006) indicate a process of construction, on different legal levels (from the police investigation to the court sentence), of travestis as banal victims whose murders are almost never solved, due to police indifference. Thus, this banalization happens even before the publication of such crimes in newspapers. Analyzing the depiction of murders of gay men and travestis by the carioca ${ }^{7}$ press between the years of 1980 and 2000 , Paula Lacerda (2006) identifies both a process of banalization of these murders and the production of what can be called culpable victims.

On the other hand, on internet posts that follow such reports, it is commonplace to see not only feelings of outrage, but also mourning, fear and sadness. In this strategy, the frequent the use of expressions like "one more" or "who is going to cry over them?" could be read as the subtext: "people like me are murdered this way. I am afraid of being killed. Imagine how it would be to live with a constant fear of dying". Despite the risk of trivializing such murders, their constant denouncement signals a desperate appeal for the recognition of this kind of violence that ultimately threatens the existence of trans people. 
${ }^{8}$ This kind of accusation can be dated back to the time when travestis entered the same movement of gays and lesbians in the mid 1990's. One of the Masters Research interlocutors referred to the marginalization of travestis in the movement, saying: "Imagine how horrible to be the leftover of the alphabet soup" (CARVALHO, 2011, p. 47).

${ }^{9}$ An analysis of the empiric materia dealing with conflicts between trans activists and feminists about these issues can be found in Carvalho \& Carrara (2015).

${ }^{10}$ According to Sérgio Carrara (1996, p. 170, emphasis on the original), "in the 1870 's, a movement was created, inspired by the campaigns for slave work eradication, and it was known as abolitionism. [...] In 1877 The British and Continental Federation for the Abolition of Prostitution was founded, with the intention to pressure different European governments to revoke regulation related to prostitution practice wherever there was a regulation". Currently, the term is still in use to refer to the positions, including in sectors of feminist movement against any form of prostitution regulation.

11 The debate about the participation of trans women in feminist spaces dates back to the 1970 's, in ountries of the northern hemisphere, especially the USA. One of the most important oppositional voices to such participation was the American Janice Raymond, who published in 1979 the book The Transsexual Empire: The Making of the SheMale. The work, produced in an intersection between academy and activism, suggested the main anti-trans arguments to feminism and, at the same time, also caused a series of theoretical stances and contestations from trans people. Among such answers, it is important to highlight: the article "The Empire Strikes Back: a Posttranssexual Manifesto" published in 1991 by Sandy Stone, a trans activist that at that time was doing her doctorate unde
Finally, I will highlight the most relevant activist use for this analysis: the debate between trans activists and other sectors of civil society, especially in LGBT and feminist forums. In these arenas, the debates happen among people with different degrees of political commitment to social struggles, commitments that we could consider as parallel, comprehensive and intersectional to trans activism. In the LGBT spectrum of these interactions, the most usual "tretas" happen around disputes related to leading roles in politics and the accusation of a certain "monopoly" of the LGBT movement by gay men activists. In these "tretas", the use of the "GGGG" category is common, in replacement of "LGBT" as a way to indicate a dissatisfaction with the proposition of agendas, claims and leading roles centered in just one of the identity categories covered by the movement ${ }^{8}$. It is important to mention that, the use of the category "GGGG" implies other accusations of hegemony such as race and class. Therefore, in sentences like "I can't stand these GGGG militants anymore", the notion that these militants would also be white and middle class is implied (and often explicit throughout the interaction).

On the feminist aspect of such interactions, the "tretas" are about two main issues: prostitution and the political subject of feminism". Regarding prostitution, the "tretas" reenact old internal debates in the feminist field between positions that defend the regulation of sex work and abolitionist positions ${ }^{10}$. The demand for participation of travestis and trans women in feminist forums, and consequently the expansion of the political subject of feminism is not a new debate (or conflict) ${ }^{11}$. On the reedition of such internet feuds, there is a recurrent use of accusatory categories such as "radfem", referring to a type of radical feminism that would consider only people assigned as women at birth as part of the political subject of feminism, and "TERF", meaning trans-exclusionary radical feminists. There is also the derogatory use of the category "piroco" to refer to travestis and trans women, in a clear allusion to "piroca" (Brazilian slang for dick), in order to delegitimize the feminine identity of these individuals.

\section{From Face-to-Face Interaction to Technology-Mediated Interaction: some contributions out of symbolic interactionism}

It is usual, not only in social movements' studies, but also in the very militant vocabulary, the use of bellicose metaphors such as struggle, confrontation, dispute, enemies, 
Donna Haraway; the pamphlet "Transgender Liberation: a movement whose time has come" published in 1992 by the activist Leslie Feinberg; and "The Transfeminist Manifesto", published in 2003 by academic and activist Emi Koyama. These three productions are strongly influenced by the poststructuralist feminism of authors such as Teresa de Lauretis, Donna Haraway and Judith Butler, as well as, in the case of Koyama, the frontier feminisms, which have in Glória Anzaldua their main expression. For further material on feminist disputes in the USA, both in activist and in academic realms, see Coacci (2014).

${ }_{12}$ For a comparative analysis between the use of the bellicose metaphor and the dramaturgical metaphor, see Monika Dowbor \& José Szwako (2013). allies, adversaries, weapons, ammunition, etc ${ }^{12}$. However, I have been following Erving Goffman's proposal (2009) about the use of the Dramaturgical Metaphor as an analytical tool of social and political interactions involving trans activists. I will not focus on a detailed view of symbolic interactionism, but rather highlight some central topics about my concern with the social interactions whose aim is political persuasion regarding the production of solidarity and mutual recognition.

Goffman's dramaturgical analysis (2009) implies a face-to-face interaction. In such interactions, the course of action of actors and actresses can change anytime as a result of cues from others involved in the interaction, impressions from the audience's behavior, changes in scene, disruptions in presentation, among other factors. They are small gestures of approval or disapproval, demonstrations of lack of interest, careless looks, yawns, laughter, changes in tone of voice, body posture, and a whole range of objective and subjective factors, which are involved in the maintenance or change of a determined course of action. In spite of that, in social interactions mediated by technology, such as those of cyberactivism, many of these factors are not available either for the actors/actresses, or for the audience. For example, when a message is written and posted on Facebook, the person who wrote it cannot perceive in the middle of the process if the message constructed is being accepted or not, thus changing her course of action in order to make the message fulfill its purpose or, as Goffman says (2009), in order to establish a well-succeeded representation.

In this way, when posting, the individual can, from previous knowledge about his contacts (and therefore receptors of the message), modulate it to reach a certain objective: to cause revolt, compassion, solidarity, contempt, etc. However, this knowledge is limited by some factors. First, the message transmitter can only suppose how the message will be received, whithout the alternative of changing the discourse or representation. Second, there is no certainty that the message will be restricted to specific audiences and the effects of sharing and multiple receptions may be unpredictable. Third, even with the existence of new graphics used on social networks sites in order to produce effects of exclamation, laughter, crying, etc., these are not capable of conveying the same variety of signals available in face-toface interactions.

One can infer my arguments are only applicable to interactions based on texting, and the constant use of video messages could overcome such barriers. Partly yes, regarding the possibility of the audience perception related to other elements that compose the representation beyond the raw 
${ }^{13}$ About the central role of internet
in the political organization of
trans men in Brazil, see Simone
Ávila (2014) and Carvalho (2015). text, such as facial expressions, gestures, tone of voice, costumes, and even the scenario involved in the representation. However, what seems more important in representations that aim at political persuasion is the capacity of the transmitter to realize how the message will be received by the audience, being able to reassess the course of discourse. Alternatively, once the message is sent as a whole, there is a decrease in the possibility of an incomplete or misunderstood comprehension due to an abrupt rupture, which could easily happen in face-to-face interactions.

If social interaction mediated by technology prevents the gathering of impressions from the audience (at most, the definition of who composes such audience), it is also free from constraints caused by such impressions that could restrain or limit the expression of a certain idea. This greater freedom of expression is dubious, though. At the same time that it allows for a wider visibility and strengthens the spreading of subaltern, dissident, or social minority speeches, it also allows the viral spreading of hate speech.

What would then be the possibilities and hindrances for reciprocal recognition in a social interaction in which one cannot see the other person? There is clearly a series of social interactions on the internet between people who know each other offline, as well as others in which reciprocal recognition is a precondition for interaction, as in closed forums of trans people and, more specifically, in the process of political organization of trans men in Brazil ${ }^{13}$. Nevertheless, my concern is the social interaction and political persuasion between those who are different, and the inherent conflicts on this issue, that is to say, the "tretas". There are three recurrent situations that prompt this questioning.

Frequently, some activists have positions that could be defined as radical, in the broad sense of the term, in many debates on the internet. Sometimes, they seem unable to recognize potential allies or people in the process of persuasion or recognition of the moral and political legitimacy of trans demands, especially when these people make comments that could be considered directly or indirectly transphobic (an example is the non-use of inclusive or genderneutral language). In such situations, the complete collapse of the process of political peruasion is common, classifying the comment or speech in question as oppressive, disregarding any political positioning that the person responsible for it may have. In other words, in a matter of seconds, or characters, a potential ally becomes persona non grata, as occurred when the famous Brazilian actress Glória Pires used the expression "sexual preference" instead of "sexual orientation", or the controversy regarding the absence of black and trans people (despite the inclusion of 
${ }^{14}$ Similar to Valentine's Day, but celebrated on June $12^{\text {th }}$ in Brazil. a gay couple) in the campaign of O Boticário for the 2015 Dia dos Namorados ${ }^{14}$, for instance.

The second situation is the great dissemination of hate speech on social networks sites. At times, highly offensive comments end up discrediting the very humanity of the other. However, as my research focus is on activist speeches and practices, I will leave out this topic.

Finally, the third situation is related to the continuous appeal to notions such as "intersectionality", "subalternity" and "standpoint" ("lugar de fala"), "queer", among other categories whose meanings are produced, reproduced and transformed in political-academic exchanges. It is not a question of scrutinizing academic concepts and production vis-à-vis activist productions over such categories. This view would assume that what is defined in academic texts is correct and that activism would make an inappropriate or distorted use of concepts in face of political pragmatism. Despite the possible criticism about their conservative stances, the considerations of Max Weber (2007) about politics and science as being different, though interconnected, fields of discourse may be relevant on this issue.

The connection or relation between activism and the academy in the context of what we now call LGBT movement has gone through several transformations throughout the last decades in Brazil: from a strong feeling of distrust regarding the real intentions of the researchers that attended the meetings of the first gay organization in Brazil, the group SOMOS ("We are") from São Paulo (MACRAE, 1990; SIMÕ̃E \& FACCHINI, 2009), to the enquiry activists made to a number of anthropologists about the best category ("sexual orientation" or "sexual preference") to use on the political demands brought to the Constituent Assembly of 1987 (CÂMARA, 2002). Regina Facchini, Marcelo Daniliauskas and Ana Cláudia Pilon (2013) track the outbreak of the epidemic of HIV/AIDS as the milestone of an ambiguous pattern in this relationship. According to the authors,

the production of scientific knowledge is evoked because of its potential of legitimization of the movement demands and its capacity to subsidize the elaboration, the implementation and evaluation of public policies; but a certain mistrust remains, since this academic knowledge, produced from other references, may also clash with activist strategies, whether occasionally or in a more significant way. (FACCHINI, DANILIAUSKAS, PILON, 2013, p. 166) ${ }^{15}$

This scenario becomes more complex with the enrollment of students involved in the student movement related to sexual diversity in postgraduate programs, especially during the last decade. In this way, it is not possible 
${ }^{16}$ Many artists involved in the coproduction of the category "transfeminism" (in Brazil and abroad) have activist paths strongly connected to academic productions related to the topic but one could also say they have academic paths connected to activist productions.

\begin{abstract}
${ }^{17}$ In the original: "As relações entre ciência e política são evidentemente muito mais complexas do que o dilema que opõe crítica, de um lado, e engajamento, de outro. É importante considerar a heterogeneidade desses dois universos e o modo como diferentes perspectivas situadas em cada um deles aproximam-se e se separam, às vezes apoiando-se e legitimando-se mutuamente, às vezes entrando em ferozes disputas. Diferentes estilos de militância e de pensamento estão em constante interação, disputando o poder de dizer o que é a realidade social e quais são, portanto, os melhores meios para transformála. Além disso, o ponto de vista dos múltiplos atores sociais que viabilizam o trabalho de investigação antropológica e que participam dessa teia de negociações e compromissos que abrem certo campo à observação incorporase, de um modo ou de outro, nos "fatos" que produzimos, configurando nosso discurso sobre eles."
\end{abstract}

to foresee a project polarization (scholars versus activists) but rather coexistence and contingent alliances (FACCHINI, DANILIAUSKAS, PILON, 2013). The transit of subjects through distinct vocations, using Weber's words, cannot be seen as a choice between a critical position expected in the academic work and a pragmatic position expected from political commitment. Not only are the political and scientific fields diverse, but also the discursive productions influence one another ${ }^{16}$. It is possible to affirm that currently there are activisms with highly critical perspectives coming from different constructionisms, as well as academic productions committed to and concerned with the pragmatism of the State actions in different areas, such as in health, education and social assistance.

Along these lines, Sérgio Carrara (2016) thus analyses the current state of the relation between anthropology and the process of LGBT citizenship in Brazil:

The relations between science and politics are clearly far more complex than the dilemma that opposes criticism, on one side, and commitment, on the other. It is important to consider the heterogeneity of these two universes and the way different perspectives coming from both of them become close or distant, sometimes supporting and legitimizing each other and sometimes engaging in feuds. Different styles of militancy and thought are in permanent interaction, fighting over the power to define what the social reality is, and consequently, which are the best means to change it. Moreover, the point of view of the multiple social actors that make the work of anthropological investigation possible, and that participate in negotiations and compromises that open a certain field to observation, embodies in one way or another the "facts" we produce, shaping our discourse about them. (CARRARA, 2016, p. 26. In press.) ${ }^{17}$

What seems more interesting for me, and disturbing at the same time, is the use of notions of "standpoint" ("lugar de fala") as a way to ensure or remove political legitimacy from the one who is speaking or writing. This notion, associated with the concept of intersectionality, appears constantly in posts that enunciate a series of social markers of the subjects involved in a given political confrontation, or "treta". Thus, phrases such as "I, as a suburbian black cis transfeminist woman" or "this forum dominated by middle-class white cis gay men" are used as self-evident proof of the compromise of different political subjects with supposedly antagonistic political projects.

There is no doubt that social markers of gender, race/ ethnicity, color, class, geographic location, sexuality, among 
${ }^{18}$ For example, the sentence "don't give opinion about a form of oppression you don't suffer" is repeatedly used on internet forums and even became a poster fixed on some streets of Rio de Janeiro.

${ }^{19}$ Spivak's debate (2010) about translation is much more complex than the view presented in this article; though it has been a source of inspiration, her theory is not the object of analysis. others, are fundamental for the construction of life and speech possibilities for political subjects. The problem is the presupposition that such social markers are automatic and unquestionable producers of a specific political project. To this process we can add a political confusion between "speaking with" and "speaking for", between alliance and protagonism. This misunderstanding causes, in the most absurd limit of political debate on the internet, the inversion of Gayatri Spivak's question (2010): it no longer has to do with "Can the subaltern speak", but with whether "only the subaltern can speak", and with the number of subalternity markers allowing for greater political legitimacy.

This conflict not only ends the dispute over "the power to say what the social reality is and what are, consequently, the best ways to change it" (CARRARA, 2016), more evident in the relation between the political and scientific fields, but it also reveals the internal struggle in the political arena for "the public microphone" (ALVAREZ, 2014). In all cases, the category "standpoint" ("lugar de fala") seems open to multiple interpretations. From a decolonial resistance to the power of scientific knowledge (mainly regarding biomedicine) to circumscribe the problems and solutions to people's lives, no matter what people have to say about themselves, passing through a strong valorization of the lived and embodied experience in the definition of the violence subjects suffer, it brings the political necessity of describing the many social specifications (frequently transformed into individuals) in terms of class, gender, race, sexuality, place of residence, etc. It even comes to the point of sanctioning opinion, or speech, over a certain topic, on the part of people who do not share any social or individual characteristic that may connect them directly to the topic in question ${ }^{18}$.

At this point, the debate over the (im)possibilities of translation of subaltern speech becomes relevant ${ }^{19}$. To a certain extent, politics depends on processes of generalization of individual questions in order to build answers from different orders. The problem remains in the translation of injustice suffered by an individual to a larger group of people, as says Honneth (1995, p. 163):

[...] motives for social resistance and rebellion are formed in the context of moral experiences stemming from the violation of deeply rooted expectations regarding recognition. [...] If these normative expectations are disappointed by society, this generates precisely the type of moral experience expressed in cases where subjects feel disrespected. Hurt feelings of this sort can, however, become the motivational basis for collective resistance only if subjects are able to articulate them within an 
${ }^{20}$ A further debate about the notion of identification bridges as a resource in the struggle for recognition can be found in Carvalho (2015).
${ }^{21}$ Trend Topics is a kind of rank of the most commented topics on Twitter through the use of tags, or hashtags, adding the symbol \# before a word or sentence that works as catchphrases, usually signaling a political position (in the case of the proper political disputes, obviously).

22 In the end of 2015 in Brazil, different groups were organized on the internet, more specifically on Facebook, to report different pages with political content in the social network site. The reports against pages with feminist and/or LGBT content were made claiming "sexually explicit content or pornography", and pages with antifeminist or anti-LGBT content were reported claiming "hate speech". In this feud, several pages were deleted and recreated in the sequence, some even with the purpose to slander one or another political view. It also became clea in this situation that the reasons for the company to delete a given content from its social network site were based on the number of reports rather than on their content. intersubjective framework of interpretation that they can show to be typical for an entire group.

Such possibility of articulation depends on the construction of identification bridges ${ }^{20}$ between different subjects, forms of violence and injustice, and situations of disrespect. However, to do so, it is necessary to change from an identity-related to a more systemic comprehension of injustice. In other words, it is not about the life specifications of a black travesti living in a carioca favela, but the intersection between transphobia, racism and urban segregation in Rio de Janeiro. Therefore, there is an epistemological contradiction: the enumeration of an increasing number of social markers of difference, which in a certain way composes a post-structuralist strategy of shattering unitary identities, ends up resulting in a sum whose result is always one, strengthening one's own identity. In other words, there is a return to a unique subject whose suffered injustice is impossible to identify in others. I dare say that this contradictory result is immersed in a neoliberal appropriation process of post-structuralist premises regarding the maintenance of value, unity and potency of the individual.

Before making further considerations about conflict and alliance, or adversaries and allies, fundamental in this process, I would like to comment on social interaction platforms on the internet. I raise here the hypothesis that the constraints, possibilities and cultural valorization related to the form of these platforms would have a direct relation with an overvaluation of social markers assigned to different individuals. For example, what are the implications in the restriction of only 140 characters on Twitter in the production of political confrontations based on catchphrases that only serve to enroll supporters in a dispute over "likes" or trending topics positions ${ }^{21}$ ? This dispute is clearer on Facebook, where the visibility of a post is proportional to its number of likes. In addition, the history of the totalitarian countermovements shows us how much easier it is to enroll a great number of people when the answers to the social problems seem simple and without relativization or contextualization. Thus, the "fight over likes" and the "war of memes" sometimes seem to transform the conflict, inherent to the political struggle itself, in a numeric dispute for followers of one or another political position, not to mention the battle to shut down Facebook pages by the end of $2015^{22}$, which undoubtedly leads us to a debate over the confusion between democratic principles of society and censorship and freedom of speech policies present in a given social network site. At most, we cannot miss the point that the North American logic of freedom of speech at any cost is central in decisions regarding the keeping or exclusion of content on social networks sites. 
23 This debate, partly inserted in the "Brazilian Civil Rights Framework for the Internet", opens another argumentative line that is not included in the scope of this article.

\footnotetext{
${ }^{24}$ The nacional exam for entrance in public universities in Brazil. 25 "The persistence of violence against women in Brazilian society".
}

Another point about the political use of such platforms is the double result of safety possibilities and non-curtailment of speech possibilities, which could happen in face-to-face interactions in which the power of hierarchical relations manifests itself in different ways of political intimidation. On the one hand, it gives voice to a subject that would otherwise not be able to speak in public, but it also opens up a vast space for hate speech and extreme violence. The point here is not exactly the damage and benefits of freedom of speech on social networks sites ${ }^{23}$, but how the economy of affections manifests in such expressions and especially on their judgment. Thus, what can be presented as autonomy and individual freedom can also figure as a trap that transforms the opinion of a person in the middle of a process of political persuasion into the speech of an aggressor, many times disregarding any possibility of political transformation in people (what largely frustrates the political purpose of social transformation through the resolution of conflicts). The one who could have become an ally furns into an enemy... and then feeds back a political culture of hate on social networks sites.

This situation leads me to the considerations of Chantal Mouffe (2000), in which human relations are crossed and formed by antagonism. In this way, the political and democratic purpose would be to move from antagonism to agonism. In the author's words:

[...] from the perspective of "agonistic pluralism" the aim of democratic politics is to transform antagonism into agonism. This requires providing channels through which collective passions will be given ways to express themselves over issues which, while allowing enough possibility for identification, will not construct the opponent as an enemy but as an adversary. An important difference with the model of "deliberative democracy" is that for "agonistic pluralism", the prime task of democratic politics is not to eliminate passions from the sphere of the public, in order to render a rational consensus possible, but to mobilize those passions towards democratic designs. (MOUFFE, 2000, p. 103)

However, the task of manipulating the economy of affection is not simple. The avalanche of Facebook posts celebrating the questions and the theme of the essay in Exame Nacional do Ensino Médio (ENEM) ${ }^{24}$ from 2015 was inevitable ${ }^{25}$ repeating the sentence: "literally, sexists will not pass". Would it be possible to defeat sexism without embodying it allegorically in the body of the sexist, white, straight, cis man? Possibly yes, but it is not an easy task. Yet, what concerns me the most is the difficulty of perception and identification of potential allies, in a kind of revisited Trotskyism 
${ }^{26}$ Here I refer to a debate over the path to a technology driven to grater possibilities of interaction, cooperation and connection in the changes of the way internet functions, that are commonly but not consensually called Web 1.0 Web 2.0 and Web 3.0: "web 1.0 technologies allow 'cognitive processes of communication', relating the user with the hypertext Web 2.0 establishes the bases for 'communicative processes', using interactive platforms, such as networks and social midia. Finally, web 3.0 would allow for 'cooperative processes', integrating data for building new information and meaning" "as tecnologias da web 1.0 permitem 'processos cognitivos de comunicação', sendo que há uma relação do usuário com o hipertexto. Já a web 2.0 cria bases para 'processos comunicativos', utilizando, para tal, plataformas interativas como as redes e mídias sociais. Por fim, a web 3.0 teria como fundamento permitir os 'processos cooperativos', realizando a integração de dados para construir novas informações e significados" (PARREIRAS, 2015, p. 29-30).

27 "E se eu fosse puta", www.eseeu fosseputa.com.br. in which you either engage fully in the political program or you are the worst enemy.

Whether the social theories available for thinking about human relations will be effective to cope with these online relations is open to debate. The technologies and possibilities of social interaction mediated by them change constantly, and any exercise to predict the path it is going to take can configure as an innocuous form of futurology. What is open here is a vast field for future research that can not only utilize the internet as a means, but can transform it in the very question to be analyzed.

Nevertheless, there are examples of possibilities of human recognition through the machine in processes in which the limits between online and offline disappear. Would then our hopes be in the hands of the cyborg?

\section{Final Considerations: or a touch of poststructuralist optimism}

The potential for reciprocal recognition in social interactions mediated by technology seem to be just in areas where the separation between online and offline disappears. The demarcation of this border is increasingly difficult, taking into account discursive production, symbolic signification and the temporal dimension of political and social developments.

There is in the literature a great topographic discussion about the internet that sometimes indicates a spatial separation of an offline/real/physical universe from an online/ virtual/afar universe. It is within this discussion that categories such as cyberspace emerge in order to restrict events, interactions, identities and speeches produced online to a specific space, where a theoretical and analytical demarcation is possible. However, the continuous advances in technology and internet access build a scenario where such separation becomes problematic from both a theoretical and an analytical point of view. Some characterizations and predictions about the potentials for social, cultural and political transformation of the internet, made less than a decade ago, sound sometimes anachronistic, especially when the remote access possibilities (with the advent of smartphones) and reformulations on the internet itself were impossible to anticipate ${ }^{26}$. These considerations lead us to think of these social interactions inside an online/offline continuum (BELELI, 2012).

Therefore, there is production of identification bridges in the face of reciprocal recognition that operate specifically in the online/offline continuum. The articles from cyber activist Amara Moira in her blog "If I were a hooker" ${ }^{27}$ give their 
${ }^{28}$ A more detailed discussion about the activism of Amara Moira can be found in Carvalho \& Carrara (2015).

${ }^{29} \mathrm{Bi}$ or Bee is a gay Brazilian slang for gay men or LGBT people in general, it is a short word for bicha which best translation would be queer.

\begin{abstract}
${ }^{30}$ In the original: "Não só um canal contra a homofobia. Um canal contra o preconceito, contra a transfobia, a bifobia, a lesbofobia, o machismo. Um canal a favor da diversão, do riso e de viver a vida do jeito que você quiser. $E$ principalmente, sendo quem você é! Canal das Bee, porque uma abelha só não produz nenhum mel."
\end{abstract}

readers access to the marginal and stigmatizing universe of the prostitution of travestis. However, the access to this universe is through a language that is interested in and oriented to the humanization of the subject travesti28.

An interesting example of this process can be seen in a YouTube channel organized by a group of young gays and lesbians, called Canal das $B^{29} e^{29}$ which has the following description:

It is not only a channel against homophobia. It is a channel against prejudice, transphobia, biphobia, lesbophobia, sexism. A channel in favor of fun, laughter and living life the way you want. And, especially, being who you are! Canal das Bee, because just one bee does not produce any honey. (Available in: $<w w w$.youtube.com/user/CanalDasBee/about $>$, last access in: 12/11/2015) ${ }^{30}$

With videos in which diverse people are interviewed, there are interesting debates. Even considering that the channel's audience is composed basically of young LGBT people, we still have to take into account the political potential provided by the range of trans visibility regimes depicted in the different programs. A significant part of Canal das Bee interviews are made with trans people. However, differently from other means of communication, the interviews are not focused on the personal experiences of gender transition, but on something specific related to the interviewee. Therefore, there have been interviews about feminism, prostitution, health services access, enrollment in college life, literary production, elections and political parties, activism, each one with a different trans person, with different paths and political positions.

Indirectly, the channel sends out the message that there are multiple forms of trans existence, beyond those available in the stigma repertoire. In addition, directly, the channel builds processes of recognition through identification bridges between the audience and the interviewee, as in the case of the interview with a travesti who had just been approved in college admission exams. In this case, the audience largely composed of young people has the possibility to identify with the whole process of college enrollment and, from this identification, produce a reciprocal recognition.

This process is possible only with the democratization of alternative media. In all this, there is a non-differentiation in the machine. I can be on other people's screens and other people on my screen. Donna Haraway's political myth of the cyborg appears on the utopic horizon of the fall of the walls that separate and segregate different social groups. 
The cyborg is resolutely committed to partiality, irony, intimacy, and perversity. It is oppositional, utopian, and completely without innocence. No longer structured by the 'polarity of public and private [...]. They are wary of holism, but needy for connection - they seem to have a natural feel for united front politics, but without the vanguard party. (HARAWAY, 1991, p. 151)

The paradox remains, and it may even be desired. If face-to-face, cues of one's humanity can be grasped by another, it is also face-to-face that one's very human existence can be nullified by the other, in the extreme of non-recognition. If face to the machine, nuances of one's humanity can be lost in likes or dislikes, it is also face to the machine that the human machine can see the face of others' humanity.

\section{Bibliography}

ALVAREZ, Sonia E. Para além da sociedade civil: reflexões sobre o campo feminista. Cadernos Pagu (43), Núcleo de Estudos de Gênero - Pagu/Unicamp, janeiro-junho de 2014, p.13-56.

ÁVILA, Simone. FTM, transhomem, homem trans, trans, homem: a emergência de transmasculinidades no Brasil contemporâneo. 2014. 243f. Tese (Doutorado Interdisciplinar em Ciências Humanas) - Centro de Filosofia e Ciências Humanas. Universidade Federal de Santa Catarina. Florianópolis, 2014.

BELELI, lara. Amores on line. In: PELÚCIO, Larissa; SOUZA, Luís Antônio Francisco da; MAGALHÃES, Bóris Ribeiro de; SABATINE, Thiago Teixeira (org.). Olhares plurais para o cotidiano: gênero, sexualidade e mídia. Marília: Oficina Universitária; São Paulo: Cultura Acadêmica, 2012. p. 56-73.

BENTO, Berenice. Brasil: país do transfeminicídio. Disponível em: <http://www.clam.org.br/uploads/arquivo/ Transfeminicidio_Berenice_Bento.pdf $>$, último acesso em 20/03/2015. Publicado em: 04/06/2014.

BUTLER, Judith. Precarious Life: the powers of mourning and violence. London, New York: Verso, 2006.

. Quadros de Guerra: quando a vida é passível de luto? Rio de Janeiro: Civilização Brasileira, 2015a.

. Relatar a si mesmo: crítica da violência ética. Belo Horizonte: Autêntica, 2015b.

CARRARA, Sérgio. Tributo a Vênus: a luta contra a sífilis no Brasil da passagem do século aos anos 40. Rio de Janeiro: Editora FIOCRUZ, 1996.

CARRARA, Sérgio. A antropologia e o processo de cidadanização da homossexualidade no Brasil. Cadernos Pagu. Campinas: Unicamp, 2016. No prelo. 
.; VIANNA, Adriana R. B. "Tá lá o corpo estendido no chão...": a Violência Letal contra Travestis no Município do Rio de Janeiro. Physis: Revista de Saúde Coletiva, Rio de Janeiro: IMS-UERJ, CEPESC, v. 16, n. 2, p. 233-249, 2006.

CARVALHO, Mario Felipe de Lima. 2011. Que mulher é essa? Identidade, política e saúde no movimento de travestis e transexuais. Dissertação (Mestrado em Saúde Coletiva) - Programa de Pós-Graduação em Saúde Coletiva (área de concentração: ciências humanas e saúde), Instituto de Medicina Social da UERJ, Rio de Janeiro.

. 2015. Muito Prazer, Eu Existo! Visibilidade e reconhecimento no ativismo de pessoas trans no Brasil. Tese (Doutorado em Saúde Coletiva) - Programa de PósGraduação em Saúde Coletiva (área de concentração: ciências humanas e saúde), Instituto de Medicina Social da UERJ, Rio de Janeiro.

CARVALHO, Mario Felipe de Lima; CARRARA, Sérgio. Em direção a um futuro trans? Contribuição para a história do movimento de travestis e transexuais no Brasil. Revista Lationoamerica: Sexualidad, Salud y Sociedad. Rio de Janeiro: IMS-UERJ, CLAM, n. 14, Dossier n. 2, p. 319-351, 2013.

CARVALHO, Mario Felipe de Lima; CARRARA, Sérgio. Ciberativismo Trans: considerações sobre uma nova geração militante. Contemporânea: comunicação e cultura. Salvador: Póscom/UFBA, v. 13, n. 2, Dossiê Temático "Internet, Feminismos e Diversidade Sexual", p. 382-399, 2015.

COACCl, Thiago. Encontrando o transfeminismo brasileiro: um mapeamento preliminar de uma corrente em ascensão. História Agora: revista de história do tempo presente, v. 1. p.134-161, 2014.

DOWBOR, Monika; SZWAKO, José. Respeitável Público... Performance e organização dos movimentos antes dos protestos de 2013. Novos Estudos - CEBRAP. n 97, p. 4355. São Paulo, novembro de 2013.

FACCHINI, Regina; DANILIAUSKAS, Marcelo; PILON, Ana Cláudia. Políticas sexuais e produção de conhecimento no Brasil: situando estudos sobre sexualidade e suas conexões. Revista de Ciências Sociais. Fortaleza, v. 44, n. 1, jan/jun, 2013, p. 161-193

GOFFMAN, Erving. A representação do eu na vida cotidiana. 17. ed. Petrópolis: Vozes, 2009.

HARAWAY, Donna J. Simians, Cyborgs and Women: The Reinvention of Nature. New York: Routledge, 1991.

HONNETH, Axel. Integrity and Disrespect: principles of a conception of morality based on the theory of recognition. Political Theory, v. 20, n. 2, p. 187-201, Maio de 1992. 
The Struggle for Recognition: The Moral Grammar of Social Conflicts. Cambridge, Massachusetts: The MIT Press, 1995.

Redistribution as Recognition: a response to Nancy Fraser. In: FRASER, Nancy; HONNETH, Axel. Redistribution or Recognition? A Political-Philosophical Exchange. Londres e Nova York: Verso, 2003, p. 110-195.

LACERDA, Paula. 2006. O Drama Encenado: assassinatos de gays e travestis na imprensa carioca. Dissertação (Mestrado em Saúde Coletiva) - Programa de PósGraduação em Saúde Coletiva (área de concentração: ciências humanas e saúde), Instituto de Medicina Social da UERJ, Rio de Janeiro.

MACRAE, Edward. A construção da igualdade: identidade sexual e política no Brasil da "abertura". Campinas: Editora Unicamp, 1990.

MOUFFE, Chantal. The Democratic Paradox. London, New York: Verso, 2000.

PARREIRAS, Carolina. Altporn, corpos, categorias, espaços e redes: um estudo etnográfico sobre pornografia online. 2015. Tese (Doutorado em Ciências Sociais) - Universidade Estadual de Campinas, Campinas, 2015. 264p.

SIMÕES, Júlio A.; FACCHINI, Regina. Na trilha do arco-íris: do movimento homossexual ao LGBT. São Paulo: Editora Fundação Perseu Abramo, 2009. 196p. (Coleção História do Povo Brasileiro)

SPIVAK, Gayatri Chakravorty. Pode o subalterno falar? Belo Horizonte: Editora UFMG, 2010.

WEBER, Max. Ciência e Política: duas vocações. São Paulo: CULTRIX, 2007.

[Recebido em 12/05/2016

e aceito para publicação em 21/09/2016]

Mario Felipe de Lima Carvalho (mariofelipec@gmail.com). Psicólogo graduado pela Universidade de São Paulo (IP-USP), mestre e doutor em Saúde Coletiva pelo Instituto de Medicina Social (IMS-UERJ) na área de concentração de Ciências Humanas e Saúde. Pesquisador no campo de gênero, sexualidade e política, tem como foco prioritário o movimento de travestis e transexuais no Brasil. 